\section{Public opinion, predistribution and progressive taxation}

Lucy Barnes

In the long run context of dramatically rising inequalities in income and wealth, the financial crisis and ensuing 'Great Recession' pose a dual challenge to egalitarian policy. Low growth and fiscal constraints provide technocratic constraints on feasible policies, as well as looming large in the ideational spaces occupied by policy-makers. But more subtly, hard economic times may provide political challenges for egalitarian policies if they undermine trust in government intervention, or promote a 'hunkering down' in policy mood (J. Alt, Preston, \& Sibieta, 2010; J. E. Alt, 1979). This paper examines public attitudes, focusing on two particular tools for shaping the distribution of income: the size of government and the progressivity of its tax structures. The news on the former is bad, for egalitarians. But in both public opinion and in economic reality, I argue that progressive tax structures provide a feasible policy response to inequality in hard times. Further, the importance of progressivity in combating inequality is not in its redistributive role, but its pre-distributive one. That is, the confiscatory element of progressive taxation does not yield high enough revenues to effect much fiscal redistribution. But in contributing to the shape of market income inequality, progressive taxation constitutes an important predistributive policy tool.

Public opinion appears to have hardened against egalitarian policy following the financial crisis. This is certainly true with regard to the size of government spending and the overall level of taxation. However, this does not imply a retreat from redistribution with regard to the structure of taxation (and possibly spending). In general, attitudes towards progressivity are both different and more favourable than those towards large government. But can progressive taxes actually achieve meaningful egalitarian progress? There is some truth in the argument that progressive tax structures do not do much to reduce inequality. However, evidence on this score considers only the mechanical effects of taxation on the difference between market and disposable income inequality; where in fact the larger effect may be on the pre-fisc distribution of income itself.

First, I present the results from some work in progress on the impact of the crisis on public attitudes to state intervention in Britain. In the context of hard times, public attitudes militate against high levels of taxation and spending, beyond any economic constraints. However, and second, there are important differences between public attitudes towards the overall size of government, and the shape it takes in terms of targeting different income groups. How does the public assess progressive tax structures? By 'progressive' we denote tax structures in which the share of income contributed to the state is an increasing fraction of income, as income increases. I present data from the UK that reflects my previous findings that progressivity is viewed more favourably than large government. Third, I show that if anything, support for progressivity has increased in the context of the Great Recession. These findings on progressivity paint a more optimistic picture for egalitarian policy.

But does this leave us with the dilemma of having effective tools for redistribution (high levels of taxation and spending) that receive little public support, and ineffective tools (progressive tax structures) that are popular? In the final section I argue that this is not the case, based on the impact of progressive taxation on the distribution of incomes
Commented [Unknown A1]: To expand it that extra 1,000 words, one way could perhaps elaborate is on your conclusion, on how these findings fit within the pre-distribution agenda.
Commented [Claudia C2]: Perhaps worth including a definition of progressive taxation in this paragraph

Commented [Unknown A3]: Reply to Claudia Chwalisz (17/09/2014, 12:21): "..." Included in para above. 
before government intervention. Recent economic research indicates not only that the progressivity of (income) taxation reduces income inequality, but also that this comes essentially at the expense of bargaining rents for top managers rather than productive activity. Public reactions to this kind of tax policy are less well explored, but the data that do exist seem to point in a favourable direction.

\section{Preferences over the size of the government budget in hard times}

Support for redistributive policies declined precipitously with the financial crisis and subsequent recession after 2007. Some have argued that the financial crisis discredited Labour's economic policies, as they came to be seen as incompetent by virtue of presiding over crisis. However, in recent research with Timothy Hicks, I have found that a large part of the turn away from redistributive policies can be accounted for by the material interests of voters as aggregate economic conditions changed.

\section{Figure 1: The effect of aggregate income changes on preferences for government intervention}

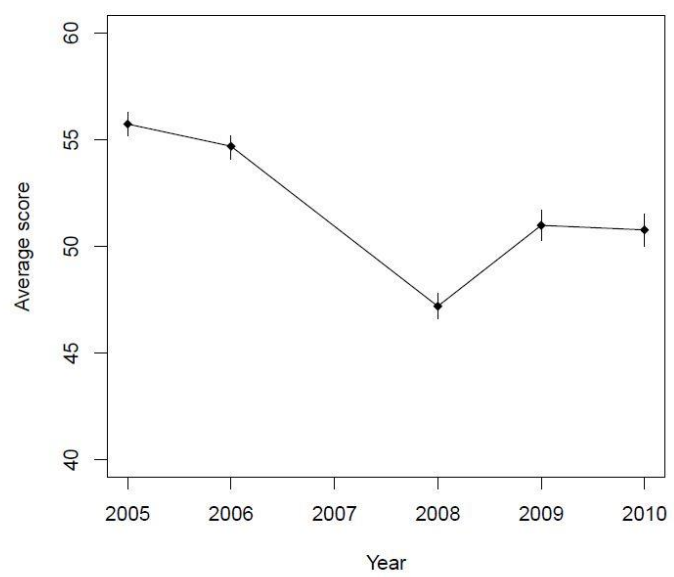

Source: British Election Study (2010); Barnes \& Hicks (2014).

Figure 1 shows the impact of the recession in raw data from the British Election Study that asks respondents whether the government should spend more on health and social services, increasing taxation, or should cut taxes, spending less on health and social services. The clear drop in the recession is partly recovered in 2009 and 2010, but attitudes towards government intervention are much more wary in hard times.

This seems to suggest a new 'Robin Hood paradox:' that when Robin Hood is most needed to redistribute from rich to poor, he is least likely to gain support. It seems this may be true not only in times of high inequality (as originally formulated), but also in times of high unemployment and low growth. Recessions look bad for egalitarian policymaking.

\section{The size versus the shape of government}

However, the size of government taxes and spending are not the only policy dimension that governments might vary according to their preferences over equality. The structure of 
taxation - its overall progressivity in particular - and the way that publicly financed benefits are distributed will also affect post-disc outcomes. This is true in the pre-crisis period, but importantly, when not only public opinion but also economic circumstance militate against high levels of spending, redistribution via the shape of government remains popular. ${ }^{1}$ In recent work, I find that across the advanced industrial countries, the modal attitude towards taxation is one of resistance to higher levels but support for higher progressivity (Barnes, 2014).

This general finding is replicated in the UK and illustrated in Figure 2. First, in the middle column we see an immediate discrepancy between views on taxes overall and taxes on the rich. Compared to the original $60 \%$, only $25 \%$ of respondents think that taxes on the rich are too high. A plurality, 37\%, think that taxes on the rich are about right. However, this acceptance of taxes paid by the rich hides a much higher demand for relative progressivity in tax policy changes. That is, most of those who think the rich pay about the right amount in taxes think that low and middle income groups pay too much. The final column of the figure takes this into account in creating a variable that captures whether the profile of responses that an individual makes when responding about the level of tax paid across income groups is progressive. For example, if we ask about taxes on high, middle and low incomes, and the response is that they are 'too low; about right; too high,' this constitutes a progressive profile, as does 'about right, too high, too high.' In contrast, saying that taxes on all groups are too low - or more realistically, too high - is not a progressive profile.

Figure 2: Attitudes towards the structure of taxation in the UK, 2006

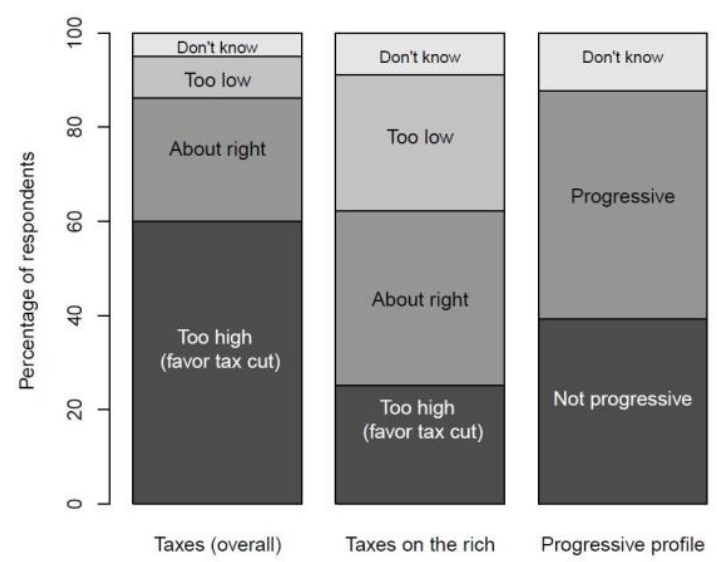

Note: Progressive type compares the attitude towards tax on the rich with the

1 In what follows I focus primarily on the tax side of the budget, but it is worth noting that the so-called 'paradox of redistribution' on the spending side - where more targeted programs undermine redistribution due to their lack of popular support - appears to have been historically limited to the pre-1990 era (Kenworthy, 2011; Marx, Salanauskaite, \& Verbist, 2013). 
respondent's attitude to taxes on other income levels. $48 \%$ of respondents overall, or $55 \%$ of those with substantive responses, have response profiles indicating preferences for relatively higher taxes on those with high incomes than those with middle and low incomes.

Source: ISSP Research Group (2006).

Under these definitions, support for progressive taxation stood at a majority $55 \%$ in the UK in 2006. Thus, even before the crisis drop in support for large government, changes to the structure of taxation were already a more favoured type of redistributive change.

\section{Support for progressivity in hard times}

Just as we saw change in support for large government in response to the economic crisis, though, we might expect to see changes in attitudes towards progressivity. In fact we do, but these changes are in the opposite direction as far as taxes on the rich are considered. Further, progressive tax policies remain popular when made as concrete policy proposals with real income brackets specified, such that not all of the support for progressive policies relies on misconceptions about what counts as 'high income.'

Figure 3 replicates the results for attitudes on taxing the rich from the 2006 ISSP, and compares them to a similar question asked by YouGov in 2012. The questions are not identical, as the ISSP asks about taxes on 'those with high incomes', while the YouGov poll asks about 'the richest people in Britain.' Thus, the implicitly higher incomes of 'the richest' rather than merely 'high' incomes may explain some of the discrepancy.

Nevertheless, it is certainly not the case that support for progressive taxes on the rich declined with the crisis in the same way as support for tax and spending levels.

Progressive tax policies also remain popular in more concrete terms, rather than the abstract notion of 'taxes on the rich'. Over the past four years, the introduction, elimination and re-proposal of the 50p rate for the highest income tax bracket has kept a concrete, progressive reform on the political agenda. In April 2009, Chancellor of the Exchequer Alistair Darling announced an increase in the top rate of tax to be paid by very high income earners: above a $£ 150,000$ threshold, income would be taxed at a rate of 50 per cent. This additional rate compares to the previous top rate of 40 per cent, which in 2010 (when the 50p rate was introduced) applied to incomes above $£ 37,400$. After the election of the coalition, the 2012 budget announced the reduction of the additional rate to $45 \mathrm{p}$. The 50p top rate made headlines, if not a reality, again in January 2014 when the shadow Chancellor promised that a Labour government would restore the higher top rate.

Figure 3: Attitudes towards the level of taxes paid by those with high incomes before and after the financial crisis 


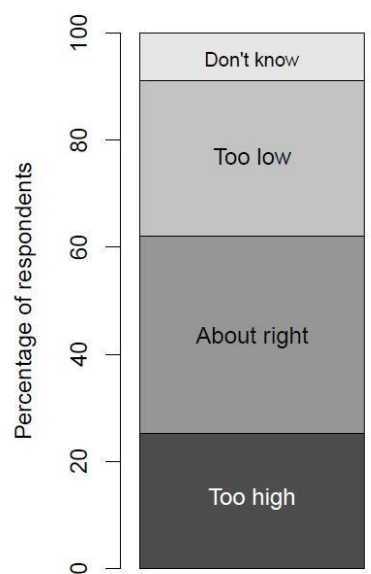

2006 ISSP

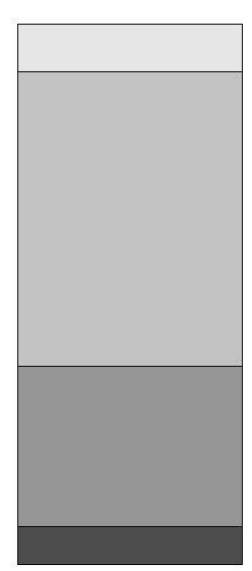

2012 YouGov

Note: The share of respondents thinking that the rich pay too little in tax increased to $55 \%$ in 2012.

Source: YouGov (2012), ISSP Research Group (2006).

As well as ensuring that the question of progressivity remained in the public eye - and in pollsters' surveys - this history provides some useful background variation against which to gauge support for progressive taxation. First, over the full period it is symmetrical in including both tax increases (the 2009 change and 2014 proposal) and a tax cut (in 2012). There are two reasons why this might be important. First, having policy proposals on both the introduction and elimination of the 50p rate means that we should be able to identify if blanket support for generic 'tax cuts' or increases drives opinion. In this case, we would see lower support for the progressive rate in response to Osborne's 2012 budget. Alternatively, the policy status quo may have an impact on preferences. The 2009 introduction of a new tax rate might be expected to provoke more resistance on the grounds of novelty (Daunton, 2001, p. 15; Rose \& Karran, 1987). This would drive our expectations in the opposite direction: once the tax is in place it would be more popular. However, the lifetime of the 50p tax may have been too short to generate any real path dependence of this sort.

Figure 4: Support for the introduction, opposition to the elimination, and support for the opposition proposal, of the $50 \mathrm{p}$ tax rate on incomes above $£ 150,000$ 


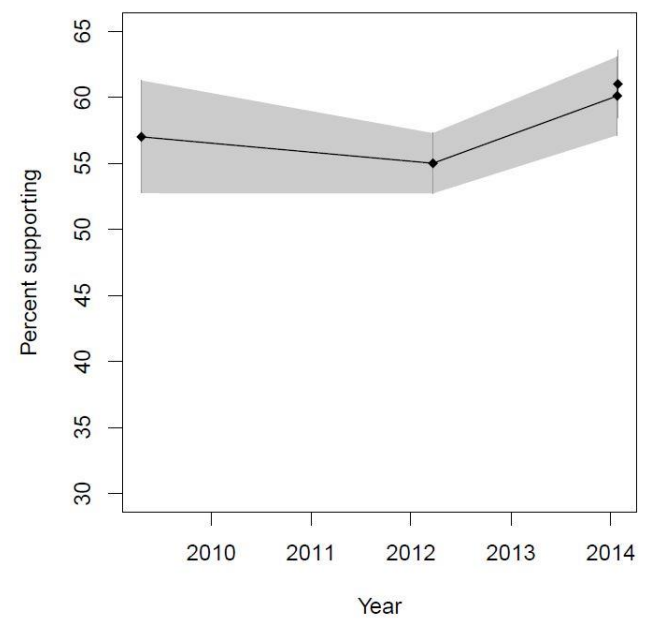

Note: The grey shaded area represents uncertainty around the estimates, denoting $95 \%$ confidence intervals for the estimated proportions. Since 2009, support for the policy has remained high and effectively unchanged, with a majority of voters in favour. Note that this is true despite the different status of the tax in relation to the status quo during this period.

Source: YouGov (2014), Survation (2014), Populus (2009), YouGov (2012).

Second, asking about a concrete tax change also mitigates concerns that everyone is in favour of taxes on 'the rich,' as long as that group is defined as those with higher incomes than themselves. By explicitly stating the cut-off of $£ 150,000$, the concrete policy question avoids this. It is worth noting that this threshold is very high in the context of the UK income distribution: for an individual without children this amount of income is well within the top $1 \%$ of the distribution in 2013 . As such, most people will not be personally affected by the additional rate. The constant bracket in a period of moderate inflation (an average of just over 3\% in the five years from 2009 to 2014) means that the number affected may have increased somewhat since the initial introduction of the top rate, but it is still a tiny share of the population who are counted as 'rich.'

Figure 4 shows support for the 50p rate in four polls taken over the five years between April 2009 and January 2014 (the precise question wording in each case is given in the Appendix), and coinciding with the events in the history of the 50p rate outlined above. The drawback of these questions is that none of them precede the financial crisis, thus they give us no leverage on whether hard times increase support for progressive taxes; but what they do show is consistently strong support for the 50p top rate over the crisis period.

Although the sample sizes in each poll are not so large as to give extremely precise estimates of the proportion supporting progressive taxation, in every poll the $50 \mathrm{p}$ top rate easily receives majority support - from around 55 to $60 \%$ of respondents. The estimates are not really precise enough to rule out that this support is entirely constant across the period; but to the extent that the minor variation estimated is systematic, it is at least consistent with expectations in the sense that support for the 50p rate is lowest when the proposal is to eliminate the top rate in 2012. That is, a bias in favour of tax cuts could explain the dip in support to the extent that it is not simply sampling variability. 
Thus, it is not only in the abstract that progressive tax policies receive popular support. Even (or perhaps especially) in economic hard times, disproportionate taxes on the rich garner broad approval from voters. The contrast with general resistance to high rates of taxation and high levels of government activity overall is pronounced. It is also important if both the size and the structure of the government budget can be used as tools to achieve distributional goals. Whether progressive tax policy can play such a role is the subject of the next section.

\section{Progressive taxes as egalitarian policy}

Public support for progressive taxation is all very well, but the scholarly consensus is that progressive structures generally do not do that much to reduce inequality (Prasad \& Deng, 2009; Cusack \& Beramendi, 2006; Kato, 2003; Ganghof, 2006). The amount of redistribution that governments do depends more on the overall size of government-raising lots of tax revenue-- than the details of the tax structure. There are two related reasons for this: first, actually existing tax structures overall are simply not very progressive. Although marginal rates within the income tax are progressive, the distribution of the tax bases across income groups undermines this effect. Second, even proportional taxes can do a lot of redistribution as long as the goods they fund are distributed more equally than the initial distribution of income. In the case of many (most) government services, even with a slightly regressive structure in their uptake the distributive 'gap' between outlays and (proportional) taxation is much larger than the gap between slightly progressive and proportional systems.

\section{Progressive taxes as pre-distributive policy}

However, redistribution in the instantaneous distribution of income - the measured difference between market and disposable incomes - is not the only way in which progressive tax policies affect inequality. In fact, there are a number of good reasons to think that highly progressive income taxation will reduce inequality in market incomes themselves. Since higher tax rates tend to reduce the size of the base they are levied on, more strongly increasing rates should reduce the difference between higher and lower incomes. This argument might be used on both sides of debates about progressivity. Lower pre-fisc inequality as the result of more progressive taxation points to behavioural responses to the tax code which might undermine economic growth (to the extent that they suppress valuable productive activity). Even if falling incomes at the top only undermine rent-shifting activities (Alvaredo, Atkinson, Piketty, \& Saez, 2013), they will nevertheless reduce government revenues to the extent that they are successful in diminishing top incomes.

I follow Piketty, Saez, and Stantcheva (2014) in outlining three behavioural mechanisms underlying an expectation that high marginal tax rates should reduce pre-fisc inequality. The first mechanism - and one which is commonly used as an argument against strongly progressive taxation - is that high taxes disincentivise effort. Since expending effort on productive activities (which generate income) is costly, reducing the returns to that effort by taxing them more strongly will cause individuals to substitute out of productive activities, and into leisure, at the margin. ${ }^{2}$

2 There is also likely to be an income effect whereby higher taxes would induce greater effort, but we ignore this for now. 
The second possibility, which also tends to weigh against high marginal rates, is that more onerous taxation may lead to more active tax avoidance. The underlying economic activity may be exactly the same, but by taking remuneration in fringe benefits, by pursuing business forms that are advantageous only for tax purposes, and so on, reported income may decline with high rates. This mechanism points primarily to the futility of high tax rates - any observed reduction in inequality is a statistical artefact rather than a true effect. It also points to some 'real' effects to the extent that energies are wasted avoiding taxation which could be more fruitfully targeted elsewhere.

Finally, high top marginal tax rates may reduce the incentives to economically inefficient abuses of managerial power in the form of rent-seeking. To the degree that managerial compensation is the outcome of wasteful bargaining efforts rather than objective performance, then high taxes on the returns of this activity generates have a positive, corrective effect.

Beyond a focus on purely individual incentives, progressive taxation may affect the pre-fisc distribution of incomes indirectly via its influence on norms of equality and fair pay. XXX Frydman, C \& Molloy, R. S. (2011) Western \& Rosenfeld (2011) Levy \& Temin (2007) Piketty Saez (2003) XXX Progressive taxation -> social norms that financial benefits not necessarily merited by success/success not measured by financial returns $->$ income inequality reductions as incentives to earn huge incomes are reduced even without reducing the incentives for professional success (rewarded in other ways(?)).

The first empirical question, then, is whether higher marginal tax rates do in fact lead to lower levels of inequality. Figure 5 shows the association between the income share of the top $1 \%$ of taxpayers and the marginal tax rates paid by those with incomes equal to five times GDP per capita, an income level approximately equal to the 99th income percentile. This is a better measure than just a top marginal rate as it keeps constant the number of people who will be affected by the rate in question. Panel (b) shows the relationship between the two variables once the independent effects of country, year, GDP, population and their interaction have been averaged out via regression analysis.

Figure 5: The relationship between progressive taxation and pre-fisc inequality

(a) Raw data

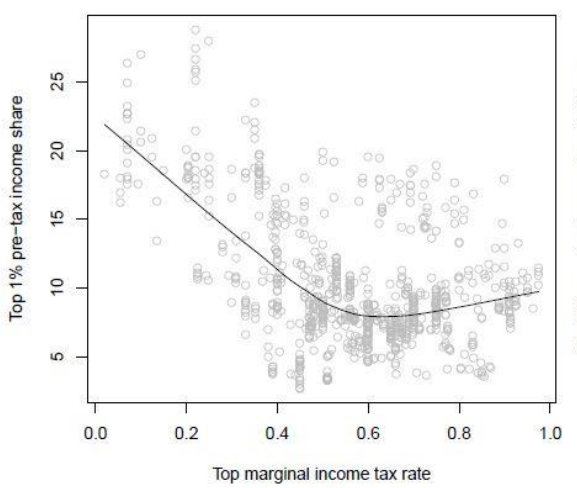

(b) Added variable plot

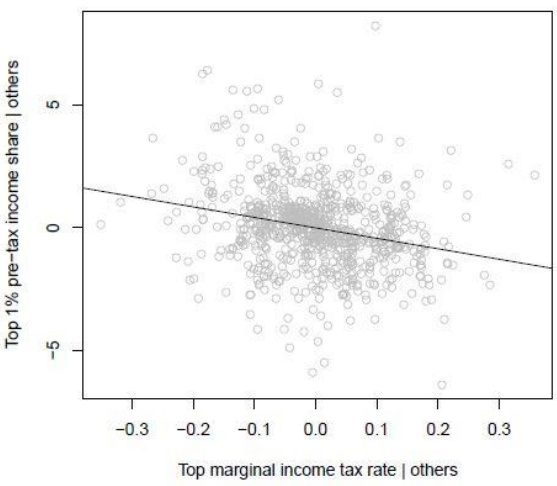

Source: Calculations based on Roine, Vlachos, and Waldenström (2009). 
The results are clear: higher marginal tax rates do seem to be associated with lower levels of inequality (as measured by the top $1 \%$ share). Although these effects cannot strictly be thought of as causal, most confounding factors will be accounted for via the country and year fixed effects. They also replicate the findings of Roine, Vlachos, and Waldenström (2009), who consider a broader range of potential confounders and also use some alternative strategies to make a causal interpretation more credible.

The impact of progressive taxation on inequality may operate less through the mechanical impact of the tax structure on fiscal redistribution, and more through its pre-distributive effects. Just as other contributions to this volume emphasise the importance of government policy in raising incomes at the lower end of the distribution (Lynch \& Bruno Palier; Busemeyer; Baziller; all this volume), progressive taxation may be one of the few tools available to governments seeking to rein in inequality at the top. This is not achieved by confiscation per se, but by changing the incentives to accumulate huge market incomes.

In this context we may be concerned by the potential impact of high top tax rates on economic growth. If the effect of highly progressive taxation on incentives to earn high incomes operates through the first channel identified by Piketty et al. (2014), progressivity may have an adverse effect on growth. This relationship, in figures analogous to those above for inequality, are shown in Figure 6 . Here, there is no evidence in the data that high tax rates undermine economic performance. This is also consistent with recent work by IMF economists who find no evidence that redistribution is harmful to growth, unlike inequality itself (Ostry \& and Charalambos G. Tsangarides, 2013).

How are these ideas reflected in public opinion? Unfortunately, to my knowledge there are no sources of data that ask respondents explicitly about whether they would be prepared to trade off growth to see income more equally distributed.

\section{Figure 6: The non-relationship between progressive taxation and economic} growth

(a) Raw data

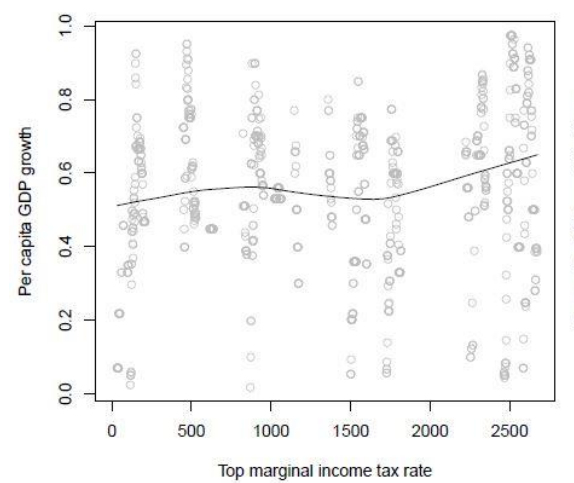

(b) Added variable plot

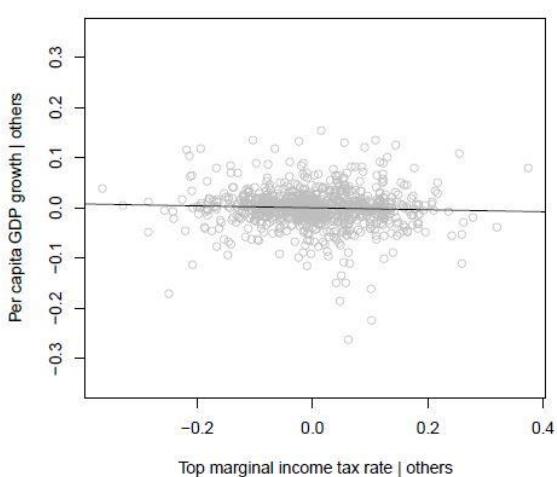

Source: Calculations based on Roine et al. (2009).

On the other hand, the idea that highly progressive tax rates may not maximise tax 
revenues is one on which the British public are surprisingly sanguine. In the same YouGov poll analysed above (YouGov, 2014), when faced with the question:

"Imagine it was the case that a top tax rate of 50p did not bring in any extra money. Which of the following would best represent your view?"

fully forty per cent of respondents thought that "A 50p top tax rate should be introduced regardless of what it brings in - it is morally right that the rich should pay higher taxes," as against only four percentage points more (44\%) who thought that such a tax should not be levied.

\section{Progressivity, Revenues and the Pre-distribution Agenda}

The two preceding sections suggest that progressive taxation should be seen as a policy with which to regulate the supply side rather than a motor for revenue generation. In this sense taxation should be at the centre of pre-distributive as well as re-distributive government policy.

However, taxation is the way in which countries raise revenues to pay for traditional redistribution as well as any spending on new social risks, or investments in education and skills. Thus taxation must play a dual role in the broader pre-distributive agenda.

\section{Conclusions}

Progressive taxation thus fits the broader redistributive agenda in acting as a regulatory, as well as a revenue-raising tool. The ways in which private actors respond to the changed incentives and social norms that more progressive tax structures generate may have a more significant impact on inequality than their pure redistributive impact. These taxes which tend not to raise large amounts of revenue, in part because they apply only at very high levels of income. To the extent that these changed incentives have limited detrimental effects on growth, they should be considered positively.

Moreover, the political popularity of progressive taxation cannot be gainsaid. In this chapter we have focused on the United Kingdom, but as Figure 2 in this chapter shows, general support for tax progressivity is replicated across the developed world. In this regard, progressive taxation may have a key place in the broader redistributive agenda. While education spending is generally popular as a priority within government spending categories (in 2013, 30 per cent of people advocated prioritising education (British Social Attitudes 2013)), the first section of this chapter showed that popular support for government spending in general may be closely constrained. Moreover, the specific predistributive policies most strongly advocated in this volume may be those which struggle to gain popular support: when choosing between recipients of social transfers, only 22 per cent of respondents favor increases for single parents and children combined-compared to 48 per cent support for prioritising pensions. Within the education sector, the new is yet worse: only 3.7 per cent of respondents favor spending on students' further education-- the locus for vocational policies of the type advocated as a key driver of predistribution. Early years intervention fares somewhat better, but there is little evidence of any groundswell of support for this kind of predistributive programof the sort enjoyed 
by progressive taxation.

The empirical evidence presented here supports the notion that tax policy in general - and progressive taxation in particular - is a tool that not only has strong popular support but also can have an important effect on the distribution of incomes. Considering three arguments against this position with reference to the empirical record and the state-ofthe-art research, we can reject the arguments (a) that progressive policy is unpopular; (b) that progressive taxation does little to help inequality; and (c) that to the extent that it helps combat inequality, progressive taxation also undermines growth. Tax policy could thus play an important role in a pre-distributive agenda oriented towards greater equality.

\section{References}

Alt, J. E. (1979). The politics of economic decline: economic management and political behaviour in Britain since 1964. Cambridge, UK: Cambridge University Press.

Alt, J., Preston, I., \& Sibieta, L. (2010). The political economy of taxation. In Institute for Fiscal Studies (Ed.), Dimensions of tax design: the mirrlees review (pp. 12041279). Oxford: Oxford University Press.

Alvaredo, F., Atkinson, A. B., Piketty, T., \& Saez, E. (2013). The top 1 percent in international and historical perspective. Journal of economic perspectives, 27 (3), 320. doi:10.1257/jep.27.3.3

Barnes, L. (2014). The size and shape of government: preferences over redistributive taxation. Socio-economic review, 10, $x$.

Barnes, L and Hicks, T. (2014). Risk, Recession and Redistribution. Working Paper.

British Social Attitudes (2013). Series EDSPEND1C, SPEND1, SOCBEN1 at www.britsocat.com, accessed 25 Oct 2014.

Cusack, T. \& Beramendi, P. (2006). Taxing work. European journal of political research, 45.

Daunton, M. (2001). Trusting leviathan: the politics of taxation in Britain, 1799-1914. New York: Cambridge University Press.

Frydman, C \& Molloy, R. S. (2011). Does tax policy affect executive compensation?Evidence from postwar tax reforms. Journal of Public Economics, 95 $(11-12), 1425-37$.

Ganghof, S. (2006). Tax mixes and the size of the welfare state: causal mechanisms and policy implications. Journal of european social policy, 15.

ISSP Research Group. (2006). International social survey programme (issp): role of government, 2006.

Kato, J. (2003). Regressive taxation and the welfare state: path dependence and policy diffusion. Cambridge: Cambridge University Press.

Kenworthy, L. (2011). Progress for the poor. Oxford: Oxford University Press.

Marx, I., Salanauskaite, L., \& Verbist, G. (2013). The paradox of redistribution revisited: and that it may rest in peace? IZA Discussion Paper Series, 7414, May.

Ostry, J. D. \& Charalambos G. Tsangarides, A. B. (2013). Redistribution, inequality, and growth. IMF Staff Discussion Note, SDB/14/02, Feb 2014.

Piketty, T., Saez, E., \& Stantcheva, S. (2014). Optimal taxation of top labor in- comes: a tale of three elasticities. American economic journal: economic policy, 6 (1), 230271. doi: $10.1257 /$ pol.6.1.230

Populus. (2009). Post budget poll - april 2009. http : / / populus . co . uk / Poll / PostBudget-Poll-April-2009/.

Prasad, M. \& Deng, Y. (2009). Taxation and worlds of welfare. Socio-economic review, 7. Roine, J., Vlachos, J., \& Waldenström, D. (2009). The long-run determinants of inequality: 
what can we learn from top income data? Journal of public economics, 93 (7-8), 974-988. doi:http : / / dx . doi . org / 10.1016 / j. jpubeco.2009.04.003

Rose, R. \& Karran, T. (1987). Taxation by political inertia: financing the growth of government in Britain. London: Allen \& Unwin.

Survation. (2014). Survation economic policy poll for the Mail on Sunday, January 25th 2014. http://survation.com/wp- content/uploads/2014/04/Economic- Policy-PollTables.pdf.

YouGov. (2012). Yougov/the sun survey 21st-22nd March 2012. http: / / cdn . yougov . com / cumulus uploads / document / yp5s1ymci9 / YG - Archives - Pol - Sunresults- 220312.pdf

YouGov. (2014). Yougov/times survey, jan 24-27 2014. http : / / d25d2506sfb94s. cloudfront.net/cumulus uploads/document/c1rz7jiy8q/YG-Archive-140127-50pTax.pdf

\section{A Survey Question Texts}

A.1 50p Tax Rate

Table 1: Survey question texts and responses coded as support for progressive taxation for Figure 4 on the 50p top tax rate

\begin{tabular}{|l|l|l|l|l|}
\hline Date & Firm & N & Question & $\begin{array}{l}\text { Responses coded } \\
\text { as support for 50p } \\
\text { rate }\end{array}$ \\
\hline Apr-09 & Populus & 518 & $\begin{array}{l}\text { I am going to read out some measures that } \\
\text { were announced by the Chancellor of the } \\
\text { Exchequer in this afternoon's budget } \\
\text { statement. Please say in each case if you } \\
\text { think it is a positive measure or a negative } \\
\text { measure, or if you think that it won't have } \\
\text { much effect either way, please say so. An } \\
\text { increase from next year in the top rate of tax } \\
\text { from 45\% to 50\% for those earning over } \\
£ 150000 .\end{array}$ & $\begin{array}{l}\text { Very positive, } \\
\text { fairly positive (vs. } \\
\text { no real effect, } \\
\text { fairly negative, } \\
\text { very negative) }\end{array}$ \\
\hline Mar-12 & YouGov & 1835 & $\begin{array}{l}\text { Do you support or oppose the following } \\
\text { policies announced by the Chancellor: } \\
\text { Cutting the top rate of income tax for people } \\
\text { earning over £150000 from 50p to 45p }\end{array}$ & $\begin{array}{l}\text { Oppose (vs. } \\
\text { support). }\end{array}$ \\
\hline Jan-14 & YouGov & 1381 & $\begin{array}{l}\text { Currently the top rate of income tax is 45p in } \\
\text { the pound for earnings over } £ 150000 . \text { Would } \\
\text { you support or oppose increasing the top rate } \\
\text { of income tax on earnings over £150000 to } \\
50 p \text { in the pound? }\end{array}$ & $\begin{array}{l}\text { Support (vs } \\
\text { oppose). }\end{array}$ \\
\hline Jan-14 & Survation & 1045 & $\begin{array}{l}\text { Shadow Chancellor Ed Balls annnounced } \\
\text { today that if Labour wins power it will raise } \\
\text { the top rate of income tax from the current } \\
45 p \text { in the pound to 50p in the pound for } \\
\text { those with earnings over } £ 150000 . T 0 \text { what } \\
\text { extent do you agree or disagree with this } \\
\text { policy? }\end{array}$ & $\begin{array}{l}\text { Agree strongly; } \\
\text { agree somewhat } \\
\text { (vs. neither agree } \\
\text { nor disagree; } \\
\text { disagree } \\
\text { somewhat; } \\
\text { disagree strongly). }\end{array}$ \\
\hline
\end{tabular}

$\mathbf{L}$ 